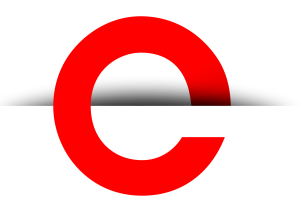

U T S

e PRES S
PORTAL Journal of Multidisciplinary International Studies

Vol. 17, No. 1/2

Jan 2021

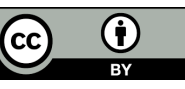

(C) 2021 by the author(s). This is an Open Access article distributed under the terms of the Creative Commons Attribution 4.0 International (CC BY 4.0) License lhttps:// creativecommons.org/ licenses/by/4.0/), allowing third parties to copy and redistribute the material in any medium or format and to remix, transform, and build upon the material for any purpose, even commercially, provided the original work is properly cited and states its license.

Citation: Wang, P. 2021. Struggle with Multiple Pandemics: Women, the Elderly and Asian Ethnic Minorities during the COVID-19 Pandemic. PORTAL Journal of Multidisciplinary International Studies, 17:1/2, 14-22. http://dx.doi. org/10.5130/pjmis.v17i1$\underline{2.7400}$

ISSN 1449-2490 | Published by UTS ePRESS I http://epress. lib.uts.edu.au/ojs/index.php/ portal
ESSAY

\section{Struggle with Multiple Pandemics: Women, the Elderly and Asian Ethnic Minorities during the COVID-19 Pandemic}

\section{Pan Wang}

Corresponding author: Dr Pan Wang, Senior Lecturer in Chinese and Asian Studies, Faculty of Arts \& Social Sciences, University of New South Wales, Sydney NSW 2052, Australia. Pan.wanglunsw.edu.au

DOI: http://dx.doi.org/10.5130/pjmis.v17i1-2.7400

Article History: Received 01/09/2020; Accepted 03/11/2020; Published 28/01/2021

\begin{abstract}
The COVID-19 pandemic resulted in hundreds of thousands of deaths in the first six months of 2020. It also exposed and led to increases in the inequalities that exist worldwide. This paper draws attention to the prejudices and biases toward three vulnerable social groups-women, the elderly and Asian ethnic minorities during the crisis. It shows that while women 'held up more than half of the sky' both inside and outside the house, they struggled against rising domestic violence and various forms of sexism. The elderly, the most at risk of infection, are being 'abandoned, 'abused' or 'obliged' to sacrifice themselves to the capitalist market economy. Ethnic minorities, especially Asian/Chinese immigrants in western countries have been subjected to racial stereotypes in their everyday life. Although the coronavirus will disappear, the 'shadow' of the pandemic will undoubtedly remain unless we rebuild solidarity and work together to reflect, reconcile and redress the inequalities entrenched in our societies.
\end{abstract}

\section{Keywords}

\section{COVID-19; Pandemic; Inequality; Gender; Ageism; Racism}

The 2020 Year of the Rat has led the world into a dark tunnel—a lethal coronavirus called COVID-19 detected in Wuhan, China in December 2019, swept across all six continents within six months from Asia to Europe, North America, South America, the Middle East, 
U T S

e PRE S S
Africa and Oceania. By 31 August it had infected more than 25 million people and killed 844,312 in 213 countries, areas and territories, leaving Antarctica the only continent free from the disease (WHO 2020). The pandemic also shattered the world economy, increased the political division between countries, disrupted the social order and amplified the long-standing inequalities embedded in the social, political and economic systems of our societies, marked by heightened gender inequality, ageism and racism in many countries and territories around the globe. In this article I draw on examples from the West and the AsiaPacific to show that such inequalities have caused a severe impact on women, the elderly and Asian ethnic minorities.

\section{Uneven Division of Labour, Domestic Violence and Sexism: Gendered Impacts on Women}

Women have held up more than 'half of the sky' both inside and outside the house during the COVID-19 pandemic. UN Women's statistics show that 70 per cent of frontline workers in the health and social sector are women, including nurses, midwives, cleaners and laundry workers (UN Women 2020a). In Hubei province, the original epicentre of the crisis in China, more than 90 percent of the frontline healthcare workers are women (UN Women 2020b). In the Americas, 86 percent of nurses are women; in Europe, 84 percent; in South-East Asia, 79 percent; in Western Pacific, 81 percent; and in Africa, 65 percent (WHO 2019: 3). Women thus face a greater risk of catching the coronavirus.

Meanwhile, women undertake 75 percent of unpaid care and domestic work in households and communities every day (UN Women 2016). This is an average of 4.1 hours of unpaid care and domestic work per day compared to 1.7 hours for men (UN Women 2020c). Since the onset of the coronavirus pandemic, different countries have imposed mandatory lockdowns, leading to the closure of schools, nurseries, care centres and other relevant services. As a result, the economy has shifted from paid to unpaid work (Lewis 2020). Although the crisis has in many instances prompted men to help with household duties, women's household burden has increased (UN Women 2020d: 12).

The COVID Caregivers survey conducted by the Boston Consulting Group from 20 March to 3 April 2020 shows that, among the 3,000 working parents in the US, the UK, Italy, Germany and France, women spend an average of 15 hours more on unpaid chores than men every week (Krentz et al. 2020). In the AsiaPacific, the International Labour Organization (ILO) found that women spend an average of 4.1 hours more on unpaid domestic labour than men on a regular day during the crisis. This figure can increase to 11 hours in some countries (Mercado, Naciri \& Mishra 2020). Given it is a common practice in the AsiaPacific region for older people to live with their children, women are expected to provide adult care as well (UN Women 2020e).

The gendered division of labour highlights the inequalities between men and women within households— the 'free labour' devoted by women is 'invisible' — unpaid and uncounted in the GDP. This invalidates 'women's essential contributions to social and community life' and contributes to the reproduction of gender inequality in everyday life (Erickson 2005: 338). It also exposes the structural inequalities in the labour market, as most women work in sectors that are hardest hit by the pandemic, including hospitality, leisure, retail and tourism. With many working part-time, having lower skilled positions and/or being paid less than men, they are more likely to lose their jobs during workplace changes. The situation is even worse for women of colour in the USA. Black women, for example, are twice as likely as white men to report financial issues such as being laid off, furloughed, or receive pay cuts (LeanIn.Org \& SurveyMonkey 2020). Ironically, women's informal work/hourly employment is typically the result of their existing childcare and family responsibilities. There are thus fewer educational and skill development opportunities available to women compared to men. 
U T S

e PRES S
The crisis has simultaneously amplified the global issue of domestic violence. Many European countries such as France, Spain, Germany and the UK have reported surging cases of domestic violence during the lockdown. Hans Kluge, director of WHO's European region, said the emergency calls made by women subjected to violence by their intimate partners had increased up to 60 percent in Europe in April 2020, compared to the same period the year before (UN 2020a). The situation was no better in the Asia-Pacific. In Singapore, the Association of Women for Action and Research (AWARE) women's helpline recorded a 33 percent increase in calls related to family violence in February compared with the same period the year before (Elangovan 2020). In Thailand, domestic violence cases almost doubled between February and April (Handley 2020). In Australia, the number of domestic and family violence victims seeking urgent assistance reportedly surged by 10 percent since the country's lockdown in March 2020. This prompted the government to inject AUD $\$ 150$ million to boost services tackling domestic violence (Cormack 2020). Also, there was an increase of 75 percent in the number of Google searches relating to domestic violence since the first coronavirus case was reported (Poate 2020). Countries including China, India, Thailand and Indonesia similarly witnessed a staggering rise in domestic violence since their respective quarantines.

On the surface, the increase in cases of domestic violence was triggered by women's long-time exposure to their abusive partners, stress and anxiety caused by various factors such as extended quarantine, financial loss and overloaded domestic duties. To borrow the UN's term, the 'shadow pandemic' alludes to the hidden and rampant gender inequalities within households around the globe. Such concealed 'normality', however, has been unmasked by the COVID-19 pandemic and brought to international attention. Such inequalities are ingrained in societies due to various cultural, religious and socio-economic factors. For instance, many women choose to tolerate domestic violence because they see it as normal marital behaviour rather than a social problem (Wang 2015: 80-81). Many women are socially and economically dependent on men, and many do not want a divorce as they see divorce as either sinful or inherently wrong. In addition, women's lack of awareness of legal protection and the unresponsiveness of local authorities to their requests for help can also aggravate such inequality within families.

Sexism has increased the gendered impacts on women during the lockdowns. Under the Movement Control Order (MCO), women in Malaysia were advised to follow the 'household happiness' posters made by The Women, Family and Community Development Ministry (KPWKM) to 'groom as usual,' ensure the home was clean during the pandemic, and to not 'nag' their husbands. If things went wrong, they were advised to mimic the voice of Doraemon, a Japanese cartoon character who speaks with a high-pitched voice, when speaking to their husbands $(\underline{\mathrm{Ng} 2020})$. In China, a sexist document published by education officials in Jinan, Shandong province on 8 February, suggested that in families with small children in which both parents were employed, women should take the initiative to apply to their employers for stay-at-home childcare during the school term delay (Global Times 2020). The policies in Malaysia and China not only reproduced gender stereotypes but also encroached on the privacy of households. Similarly, women scientists from North America and Europe claimed that the overarching scientific response to the pandemic has been sexist as women medical professionals (and leaders of colour) involved in COVID-19 research/practice have been underrepresented in the media (Buckee et al. 2020). This gendered discrepancy in science/academia ultimately reinforces the supremacy of (white) male power in the public health sector and hampers women's career advancement. Overall, as noted by the United Nations, this pandemic could undermine decades of advancement on gender equality (UN 2020b).

\section{Ageism: Economy over the Elderly?}

It is disheartening that aged care centres became the 'hotspots' of the pandemic. According to a statement made by Hans Kluge from WHO, older people are at highest risk from COVID-19. Some 95 percent of COVID-19 deaths were among people aged over 60, and more than half of all deaths involved people aged 
U T S

e PRES S
80 or above (luge 2020). Moreover, older adults tend to have weaker immune systems and are likely to have pre-existing health conditions, such as cardiovascular disease, diabetes, or respiratory illness ( $\underline{\text { Sandoiu }}$ 2020). These all increase the risk of infection and diminish the chances of surviving the crisis. In addition, older people with dementia or similar forms of cognitive impairment may have difficulty understanding the dangers of infection, forget to follow hygiene rules or safety precautions such as washing hands or maintaining social distance ( $\underline{\text { Sandoiu 2020). }}$. Many, also, have difficulty communicating clearly with others and hence may be unable to receive the help they need.

It's even more disappointing that the pandemic has magnified the problem of elderly abuse and abandonment. Such wrongdoings were widespread at the start of the pandemic in Europe, prompting Italians to name the pandemic the 'silent massacre' of the elderly and many families in Milan made allegations against nursing homes' mishandling of the crisis (Privitera 2020). In Spain, soldiers sent to disinfect nursing homes found elderly residents either abandoned or dead in their beds (Bilefsky 2020). In Montreal, Canada, older residents at a nursing home named Residence Herron were found 'dehydrated, unfed for days and lying listless in bed.' Some were covered in excrement, others had fallen to the floor while two deaths had gone unnoticed for days (Bilefsky 2020). A similar phenomenon was witnessed in Melbourne, Australia where many elderly residents were left dead in their beds for up to six hours at Epping Gardens Aged Care, while a get-together function was being held by staff ( $\underline{\text { Smith 2020)}}$.

The situation worsened in some countries when policymakers demanded prioritizing the economy over the lives of the elderly and the weak. For example, following US President Donald Trump's call to 'open up the country for business' in March, Texas Lieutenant Governor Dan Patrick said in an interview with FOX News that 'we should get back to work,' suggesting that grandparents like himself should be willing to sacrifice themselves to help the country's economy (Danpatrick.org 2020). In the same month, Ukraine's former health minister Illia Yemets commented on different occasions that we should 'Calculate how much money we need to allocate for the living people, not for the corpses [people aged over 65],' adding 'this virus does not affect children, now all the pensioners will die' (Sorokin 2020).

Prioritizing the economy is not a focus of a few powerful politicians. On social media including Twitter, Instagram and Facebook, 'millennials' used the term 'boomer remover' to refer to the coronavirus with reference to the high mortality rate among older people (60+) infected with COVID-19. Some even used The Simpsons cartoon to claim that the virus was the earth's revenge on the Baby Boomer generation (those born between 1946 and 1964 during the post-World War II baby boom) (Godfrey 2020). In Japan, a coronavirus cartoon was posted on Twitter in March 2020 with the comment 'Hope this achieves earlier.' It received 71,000 likes and was retweeted 16,000 times (@hashimotoganjia on Twitter 21 March 2020). It reveals how the younger workforce in Japan feels burdened by the aged population, a problem conveniently solved by the coronavirus as it has helped to remove (or kill) the old. Although the offensive term and cartoons used by the millennial generation are by no means representative, they do expose the tensions and division between the two generations triggered by various factors including changing demographics (ageing), deepening economic recession and disputes over issues such as inaction on climate change.

Meanwhile, older coronavirus patients are further marginalised-doctors in countries such as Italy, Spain and the UK were confronted by the moral dilemma of deciding who should continue to live when there is a shortage of ICU beds and ventilators - the sickest patients or people, usually younger, with greater chance of survival (Seegert 2020)? In Italy's worst-hit region, a front-line doctor reportedly said in March that due to the limited number of respirators available, patients over the age of 60 could not be connected to a ventilator, prioritizing instead younger patients (Ferguson 2020). In Switzerland, the Switzerland Academy of Medical Sciences' guidance for triage decisions stipulates that when no ICU beds are available, people

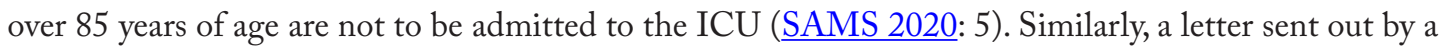
Welsh surgery in the UK asking patients to sign the 'DNACPR' form [Do Not Attempt Cardiopulmonary Resuscitation] aimed to direct scarce medical resources and emergency services to the young and fit and 
away from the old and ill as the former were considered to have a greater chance of surviving. The letter asks mostly old and ill people to agree that 'in the event of a sudden deterioration in your condition because [of] COVID infection or disease progression the emergency services will not be called and resuscitation attempts to restart your heart or breathing will not be attempted' (Busby 2020). The letter upset many patients and resulted in an apology by the surgery.

While the higher number of deaths among older adults highlights the biological vulnerability of the old and ill to the pandemic, it also underlines a series of social and moral issues that are inadequately addressed. These include dysfunction, poor staffing and lack of care in nursing homes and the socially engrained, widespread ageism outlined by Butler (1980): 1) prejudice against older adults 2) discrimination against older adults and 3) institutional practices and policies supporting stereotypes and reducing opportunities for older adults. Altogether, whether intended or not, these ageist practices may reinforce each other and have harmful effects on the mental and physical health of the senior population. This can also de-personalise vulnerable groups and render them 'lower-class' citizens or even lesser human beings. The pandemic has stretched health systems to the verge of collapse. Ageism may not only topple the system but also have an impact on solidarity.

\section{Sinophobia, Xenophobia and Prejudice: Resurrection of the 'Yellow Peril'?}

I am a Chinese-Australian living in Sydney. In April, when a 'white' woman shopper saw my friend and I buying two packs of toilet paper in a Coles supermarket in my local community, she yelled at us: 'Do not sell it to China!' When we were about to pay for the groceries at the check-out counter, the operator confiscated one pack and put it underneath her counter. She uttered 'you two can only purchase ONE!' She was supported by the store manager. This incident ended with the Coles Headquarters issuing an apology to us as the local store violated the policy of 'one customer one pack' for the pandemic period (with notices visible throughout the store).

The COVID-19 pandemic caused a frenzy of toilet paper-buying in Australia from March to April. This panic buying led to a shortage of toilet paper and triggered a higher than usual demand for the product. Stocks of toilet paper were limited and a source of friction. Reflecting on my unpleasant experience at the supermarket, such friction was intertwined with racism and institutionalised prejudice against ethnic minorities-apparently, the woman shopper was ignorant of the fact that 40 percent of Australia's toilet paper is imported from China and in her imagination, we (buyers of Asian appearance) were purchasing agents intending to capitalize on the 'toilet paper business' during the pandemic.

My experience is, however, dwarfed by the 'blunt' racism (both verbal and physical assault) others have experienced since the start of the pandemic. Hundreds of COVID-19 related racist incidents against Asians in Australia include Chinese students physically attacked by strangers in the Melbourne CBD (Woolley 2020); a Woolworths employee in Western Australia 'aggressively' prevented customers with an Asian look from entering the store for fear they will spread coronavirus ( Australian teenagers publicly shamed Vietnamese-Australian sisters by calling them 'Asian whore, 'Asian dogs, 'Asian sluts' and spat in their eyes and faces ( $\underline{\operatorname{Tan} 2020})$. The rise in pandemic-inflicted racial abuse highlights the gap in Australia's human rights legislation given there is no federal law punishing racist acts as a crime (Tan 2020). This is despite racist acts being deemed 'unlawful' in the Racial Discrimination Act 1975 (Section 18C, Australian Government 1975).

Similar actions, including racism against non-Asian ethnic minorities and prejudice within the same ethnic groups, were reported in numerous countries and regions. For example, in the US, after the start of the pandemic, vendors on Amazon started to sell T-shirts with coronavirus Chinese national flags, as well as T-shirts and mugs with the catchy slogan 'Coronavirus made in China.' In Hong Kong, South Korea and 
U T S

e PRE S S
Vietnam, local businesses, including restaurants, shops, beauty stores, hotels and taxis either posted online messages or displayed signs at their premises barring mainland Chinese customers and non-locals (Rich 2020). In Singapore and Malaysia, tens of thousands of residents signed petitions to ban Chinese nationals from entering their countries. In China, African nationals were reportedly evicted from their homes by local police in Guangzhou for fear they were spreading coronavirus. In Saudi Arabia, the image of a South Asian migrant worker dressed as a human hand sanitiser while wearing a face mask for Saudi's oil giant Aramco went viral and sparked great controversy on social media (Aljazeera News 2020). And in Australia, when Melbourne became the epicentre of the coronavirus in July, a Sydney local pub placed a sign labelled 'Chinese coronavirus plan' with the words 'if you are from Melbourne or look like you are, you will be asked to leave' (9News 2020). These incidents reveal growing mistrust and division among social and ethnic groups.

The rising racist sentiments have been fuelled by media coverage of the COVID-19 pandemic. In January alone, numerous media outlets published reports containing anti-Chinese sentiment. The Danish newspaper Jyllands-Posten used the coronavirus particles to represent the Chinese national flag; the Sydney-based Australian newspaper The Sun-Herald called the novel coronavirus a 'Chinese virus' and 'pandemonium' on its front page. The American Wall Street Journal published a similar opinion piece titled 'China is the real sick man of Asia.' And in France, a regional newspaper Le Courrier Picard warned of a 'yellow alert'/'yellow peril' in its headline (a racist term originating in the 19th century that suggests Asian immigrants/laborers are 'uncivilized,' 'dangerous' and posed serious threats to the 'civilized West'). These reports sparked outrage on social media as they served to reproduce stereotypes of Chinese/Asians and perpetuated racial discrimination against Asian ethnic minorities. These reports simultaneously violated the guidelines issued by the WHO in 2015 that specified that disease names shall not include 'geographical locations' including cities, countries, regions and continents or draw references to a particular culture or population ( $\underline{\mathrm{WH}}$ 2015: 3).

As Erin Chew, national convener of the Asian-Australian Alliance stated, 'anti-Chinese sentiment' was just a 'symptom' of the broader issue of 'anti-Chinese sentiment,' fuelled by public discussions about China's growth and influence (in Australia) in recent years (Yang 2020). This attitude may also apply globally as the rising racism against Chinese/Asians can be interpreted as a reflection of the deep-rooted and still prevalent notion of 'yellow peril' in some (western) countries. The difference is that the modern 'yellow peril' has 'transformed into something else to adapt to modern-day racism' (Yang 2020).

Overall, the COVID-19 pandemic has exposed multiple 'pandemics' embedded in our everyday lifegender inequality, domestic violence, sexism, ageism, and racism. This has placed severe and long-lasting impacts on vulnerable groups including women, the elderly and Asian ethnic minorities. It has also revealed a chain of inequalities entrenched at different levels and exercised by different parties-government, media, institutions and individuals. However, these inequalities are merely the tip of an iceberg as many remain hidden, undiscovered and unmentioned in this paper. Such inequalities will presumably be further exacerbated when they intersect with various factors such as gender, ethnicity, class or disability. Among all the dilemmas brought about by the COVID-19 pandemic, however, perhaps there is some positive light. The coronavirus pandemic has made the inequalities more overt. It is time for us to work together to reflect, reconcile, and redress the inequalities and rebuild our solidarity.

\section{References}

9news. 2020, 'Hotel in Sydney's Eastern Suburbs Called Out for Racist Coronavirus Signs,' 21 July. Online, available: https://www.9news.com.au/national/hotel-in-sydneys-eastern-suburbs-called-out-for-racist-coronavirussigns/45f87f67-d257-4df4-9444-eb7ca18361af [accessed 17 August 2020]. 
U T S

e PRE S S
Aljazeera News. 2020, 'Saudi Aramco Slammed over Migrant Worker Dressed as Sanitiser,' 11 March. Online, available: https://www.aljazeera.com/news/2020/03/saudi-aramco-slammed-migrant-worker-dressedsanitiser-200311080510084.html [accessed 17 August 2020].

Australian Government. 1975, Racial Discrimination Act 1975. Online, available: https://www.legislation.gov.au/ Details/C2016C00089 [accessed 17 August 2020].

Bilefsky, D. 2020, '31 Deaths: Toll at Quebec Nursing Home in Pandemic Reflects Global Phenomenon,' The Nerw York Times, 16 April. Online, available: https://www.nytimes.com/2020/04/16/world/canada/montreal-nursing-homescoronavirus.html [accessed 16 July 2020].

Buckee, C., Hedt-Gauthier, B., Mahmud, A., Martinez, P., Tedijanto, C., Murray, M., Khan, R. \& Menkir, T. 2020, 'Women in Science are Battling both Covid-19 and the Patriarchy', Times Higher Education, 15 May. Online, available: https://www.timeshighereducation.com/blog/women-science-are-battling-both-covid-19-and-patriarchy\# [accessed 16 August 2020].

Busby, M. 2020, 'Welsh Surgery Apologises over “Do Not Resuscitate” Instruction', The Guardian, 1 April. Online, available: https://www.theguardian.com/society/2020/mar/31/welsh-surgery-says-sorry-after-telling-the-very-ill-notto-call-999 [accessed 17 August 2020].

Butler, R. N. 1980, 'Ageism: A Foreword,' Journal of Social Issues, vol. 36, no. 2: 8-11. https://doi. org/10.1111/j.1540-4560.1980.tb02018.x

Cormack, L. 2020, 'Domestic Violence Victims Seeking Help Rises 10 Per Cent after COVID-19 Lockdown,' Sydney Morning Herald, 1 May. Online, available: https://www.smh.com.au/national/nsw/domestic-violence-victims-seekinghelp-rises-10-per-cent-after-covid-19-lockdown-20200501-p54oxt.html [accessed 16 August 2020].

Danpatrick.org. 2020, 'Lt. Gov. Dan Patrick on Tucker Carlson Tonight,'23 March. Online, available: https://www. danpatrick.org/tucker-carlson-tonight-march-23-2020/ [accessed 16 July 2020].

Elangovan, N. 2020, 'COVID-19: Counsellors Watching Out for Expected Rise in Family Abuse Victims Seeking Help,' Today Online, 8 April. Online, available: https://www.todayonline.com/singapore/covid-19-counsellors-watchingout-expected-rise-family-abuse-victims-seeking-help [accessed 16 August 2020].

Erickson, J. R. 2005, 'Why Emotion Work Matters: Sex, Gender, and the Division of Household Labor,' Journal of Marriage and Family, vol. 67, no. 2: 337-351. https://doi.org/10.1111/j.0022-2445.2005.00120.x

Ferguson, E. 2020, 'Coronavirus Tragedy: OAPs No Longer Given Respirators, Warns Doctor on Frontline,' Express, 23 March. Online, available: https://www.express.co.uk/news/world/1258895/coronavirus-Italy-latest-covid19-newsrespirators-elderly-high-risk [accessed 17 August 2020].

Global Times. 2020, 'Jinan Slammed for Asking Employed Women to Take Care of Kids at Home as Schools Close amid Virus Outbreak,' 18 February. Online, available: https://www.globaltimes.cn/content/1180043.shtml [accessed 16 August 2020].

Godfrey, A. 2020, 'Millennials' Shocking New Term for Coronavirus-'Boomer Remover,' 7 Nerws, 30 March. Online, available: https://7news.com.au/lifestyle/health-wellbeing/millennials-shocking-new-term-for-coronavirus-boomerremover-c-770457 [accessed 17 August 2020].

Handley, E. 2020, 'COVID-19 Pandemic Leads to Rise in Violence against Women and Girls in Asia Pacific, New Report Shows,' $A B C$ News, 22 July. Online, available: https://www.abc.net.au/news/2020-07-22/violence-againstwomen-and-girls-asia-pacific-covid-19-report/12476030 [accessed 16 August 2020].

Kluge, H. 2020, 'Statement - Older People are at Highest Risk from COVID-19, but all Must Act to Prevent Community Spread.' Online, available: https://www.euro.who.int/en/health-topics/health-emergencies/coronavirus- 
U T S

e PRES S covid-19/statements/statement-older-people-are-at-highest-risk-from-covid-19,-but-all-must-act-to-preventcommunity-spread [accessed 16 July 2020].

Krentz, M., Kos, E., Green, A. \& Garcia-Alonso, J. 2020, 'Easing the COVID-19 Burden on Working Parents,' Boston Consulting Group, 21 May. Online, available: https://www.bcg.com/publications/2020/helping-working-parents-easethe-burden-of-covid-19 [accessed 15 August 2020].

LeanIn.Org \& SurveyMonkey. 2020, 'The Coronavirus is a Financial Crisis for Women,' 10 April. Online, available: https://leanin.org/article/the-coronavirus-is-a-financial-crisis-for-women [accessed 16 August 2020].

Lewis, H. 2020, 'The Coronavirus is a Disaster for Feminism,' The Atlantic, 19 March. Online, available: https://www. theatlantic.com/international/archive/2020/03/feminism-womens-rights-coronavirus-covid19/608302/ [accessed 15 August 2020].

Mercado, L., Naciri, M. \& Mishra, Y. 2020, 'Women's Unpaid and Underpaid Work in the Times of Covid-19,' Amnesty International, 1 June. Online, available: https:/www.amnesty.org/en/latest/campaigns/2020/06/womens-unpaid-andunderpaid-work-in-times-of-covid19/ [accessed 15 August 2020].

Ng, K. 2020, 'Coronavirus: Malaysia Sparks Outrage after Telling Women to Wear Makeup at Home during Lockdown,' The Independent, 31 March. Online, available: https://www.independent.co.uk/news/world/asia/coronavirusmalaysia-outrage-women-ministry-makeup-lockdown-a9437851.html [accessed 16 August 2020].

Poate, S. 2020, '75\% Increase in Domestic Violence Searches since Coronavirus,' NBN News, 31 March. Online, available: https://www.nbnnews.com.au/2020/03/31/dvsearches-coronavirus/ [accessed 16 August 2020].

Privitera, G. 2020, “The “Silent Massacre” in Italy's Nursing Homes,” Politico, 30 April, Online, available: https://www. politico.eu/article/the-silent-coronavirus-covid19-massacre-in-italy-milan-lombardy-nursing-care-homes-elderly/ [accessed 16 July 2020].

Rich, M. 2020 'As Coronavirus Spreads, So Does Anti-Chinese Sentiment,' The New York Times, 30 January. Online, available: https://www.nytimes.com/2020/01/30/world/asia/coronavirus-chinese-racism.html [accessed 17 August 2020].

Rolfe, B. 2020 'Woolworths Employee “Kicks Out Asian Customer” over Coronavirus Fears,” Yahoo Newws, 1 February. Online, available: https://au.news.yahoo.com/woolworths-employee-kicked-asian-customer-out-of-supermarket-overcoronavirus-fears-020043272.html [accessed 17 August 2020].

SAMS. 2020, ‘COVID-19 Pandemic: Triage for Intensive-care Treatment under Resource Scarcity,' Swiss Medical Weekly, 24 March. Online, available: https://smw.ch/article/doi/smw.2020.20229 [accessed 3 November 2020].

Sandoiu, A. 2020, 'The Impact of the COVID-19 Pandemic on Older Adults,' Medical News Today, 19 March. Online, available: https://www.medicalnewstoday.com/articles/the-impact-of-the-covid-19-pandemic-on-older-adults\#Oldage-and-preexisting-health-conditions v/ [accessed 16 July 2020].

Seegert, L. 2020, 'Are Older Lives Less Worthy in a Pandemic?', Association of Health Journalism, 27 March. Online, available: https://healthjournalism.org/blog/2020/03/are-older-lives-less-worthy-in-a-pandemic/ [accessed 17 August 2020].

Smith, R. 2020, 'Staff Stood Down over “Extremely Serious Breach” at Epping Gardens Nursing Home,' Nerws.com.au, 29 July. Online, available: https://www.news.com.au/national/victoria/news/staff-stood-down-over-extremely-seriousbreach-at-epping-gardens-nursing-home/news-story/95d159d074038d747decf7431d147e29 [accessed 16 July 2020].

Sorokin, O. 2020, 'Amid COVID-19 Pandemic, Ukraine’s Health Minister Calls People over 65 'Corpses,' Kyiv Post, 26 March. Online, available: https://www.kyivpost.com/ukraine-politics/amid-covid-19-pandemic-ukraines-healthminister-calls-people-over-65-corpses.html?cn-reloaded=1 [accessed 16 July 2020]. 
U T S

e PRES S
Tan, S. L. 2020, “You Chinese Virus Spreader”: After Coronavirus, Australia has an Anti-Asian Racism Outbreak to Deal with,'S South China Morning Post, 30 May. Online, available: https://www.scmp.com/week-asia/people/ article/3086768/you-chinese-virus-spreader-after-coronavirus-australia-has-anti [accessed 17 August 2020].

UN. 2020a, WHO Warns of Surge of Domestic Violence as COVID-19 Cases Decrease in Europe, 7 May. Online, available: https://unric.org/en/who-warns-of-surge-of-domestic-violence-as-covid-19-cases-decrease-in-europe/ [accessed 16 August 2020].

UN. 2020b, Policy Brief: The Impact of COVID-19 on Women, 9 April. Online, available: https://www.un.org/ sexualviolenceinconflict/wp-content/uploads/2020/06/report/policy-brief-the-impact-of-covid-19-on-women/policybrief-the-impact-of-covid-19-on-women-en-1.pdf [accessed 16 August 2020].

UN Women. 2016, Unpaid Care and Domestic Work: Issues and Suggestions for Viet Nam, Online, available: https://www2. unwomen.org/-/media/field\%20office\%20eseasia/docs/publications/2017/01/unpaid-care-and-domestic-work-en. pdf?la=en\&vs=435 [accessed 15 August 2020].

UN Women. 2020a, COVID-19: Women Front and Centre, 20 March. Online, available: https://www.unwomen.org/en/ news/stories/2020/3/statement-ed-phumzile-covid-19-women-front-and-centre [accessed 14 August 2020].

UN Women. 2020b, The COVID-19 Outbreak and Gender: Regional Analysis and Recommendations from Asia and the Pacific (May 2020), 19 May. Online, available: https://reliefweb.int/report/world/covid-19-outbreak-and-genderregional-analysis-and-recommendations-asia-and-pacific-may [accessed 15 August 2020].

UN Women. 2020c, Policy Brief: The Impact of COVID-19 on Women, 9 April. Online, available: https://www.unwomen. org/-/media/headquarters/attachments/sections/library/publications/2020/policy-brief-the-impact-of-covid-19-onwomen-en.pdf [accessed 15 August 2020].

UN Women. 2020d, Unlock the Lockdown. Online, available: https://data.unwomen.org/sites/default/files/documents/ COVID19/Unlocking the lockdown UNWomen 2020.pdf [accessed 15 August 2020].

UN Women. 2020e, Surveys Show that COVID-19 Has Gendered Effects in Asia and the Pacific, 29 April. Online, available: https://data.unwomen.org/resources/surveys-show-covid-19-has-gendered-effects-asia-and-pacific [accessed 15 August 2020].

Wang, P. 2015, Love and Marriage in Globalizing China, Abingdon: Routledge.

WHO. 2020, Coronavirus Disease (COVID-2019) Dashboard. Online, available: https://covid19.who.int/?gclid=Cj0K CQjwv7L6BRDxARIsAGj-34qJqWZMqfEldMsuZ 2eSskOc0sXHX5i3Bz8bcW4MlCc-6a3t0EKejkaAmlEEALw_ wcB [accessed 1 September 2020].

WHO. 2015, World Health Organization Best Practices for the Naming of New Human Infectious Diseases. Online, available: https://apps.who.int/iris/bitstream/handle/10665/163636/WHO HSE FOS 15.1 eng. pdf;jsessionid=2D3ACAB4EFA659E7DA31BCE3BB910725? sequence=1 [accessed 11 August 2020].

WHO. 2019, Gender Inequity in the Health Workforce: Analysis of 104 Countries. Online, available: https://apps.who.int/ iris/bitstream/handle/10665/311314/WHO-HIS-HWF-Gender-WP1-2019.1-eng.pdf [accessed 15 August 2020].

Woolley, S. 2020, 'Coronavirus: University of Melbourne International Students Assaulted in Unprovoked Racist Attack,' 7 News, 17 April. Online, available: https://7news.com.au/lifestyle/health-wellbeing/coronavirus-university-ofmelbourne-international-students-assaulted-in-unprovoked-racist-attack-c-983675 [accessed 17 August 2020].

Yang, S. 2020, 'Video Shows Chinese Women being Racially Attacked in Melbourne over Coronavirus,' $A B C$ Nerws, 6 May. Online, available: https:/www.abc.net.au/news/2020-05-06/coronavirus-woman-racist-attack-inmelbourne/12216854? nw=0 [accessed 11 August 2020]. 